\title{
Improvement of subsoil physicochemical and microbial properties by short-term fallow practices
}

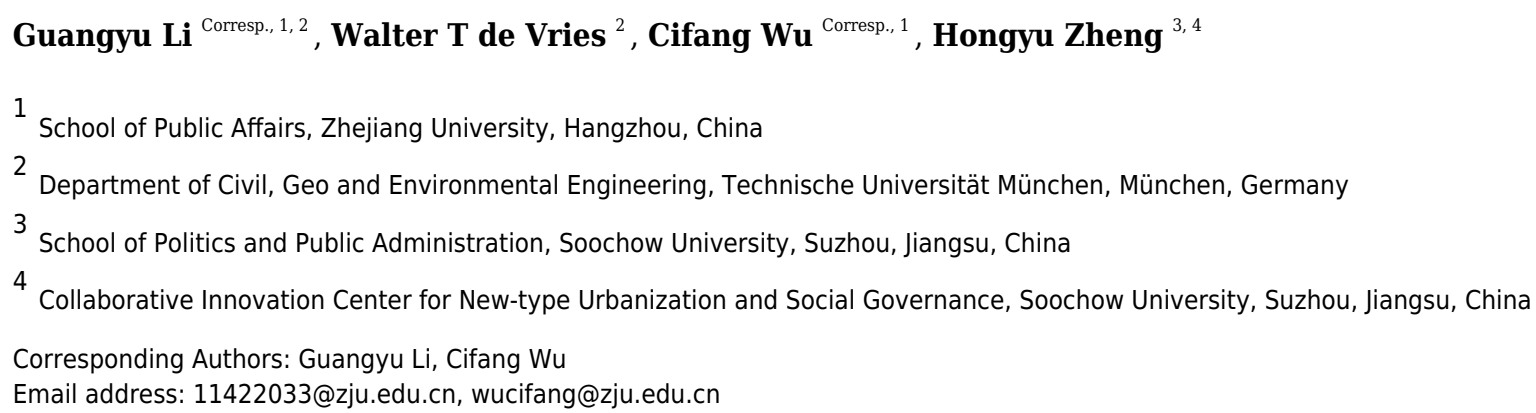

Fallow management can improve the soil nutrients in the topsoil and upper subsoil. However, little is known about the effects of short-term (one year) fallowing with different treatments, such as vegetation and fertilization, on subsoil $(20-40 \mathrm{~cm})$ properties. We conducted field trials to explore the changes in subsoil properties in response to such treatments in the Yellow River Delta region in China. Different vegetation and fertilization treatments were applied, and we measured the carbon and nitrogen contents, microbial biomass and microbial community structure in the subsoil. Fallowing without manure resulted in the storage of more total nitrogen (16.38\%) than fallowing with manure, and meadow vegetation improved the ammonium nitrogen content $(45.71 \%)$ relative to spontaneous vegetation. Spontaneous vegetation with manure improved the microbial biomass nitrogen $(P<0.05)$. Although the impact of short-term fallowing on microbial community structure was low, an effect of management was observed for some genera. Blastopirellula, Lysobacter, and Acidobacteria Gp6 showed significant differences among fallow treatments by the end of the year $(P<0.05)$. Blastopirellula abundance was related to the microbial biomass nitrogen and nitrogen mineralization rate in the subsoil. Manure retained a high abundance of Lysobacter, which may strengthen soil-borne disease resistance. The response of Acidobacteria Gp6 showed that meadow vegetation without manure may not benefit future crops. Although the treatments did not significantly improve microbial community structure in the one-year period, annual fallowing improved certain subsoil properties and increased the number of functional genera, which may enhance crop productivity in the future. 


\section{Improvement of subsoil physicochemical and}

\section{2 microbial properties by short-term fallow practices}

3

4

Guangyu $\mathrm{Li}^{1,2}$, Walter T. de Vries ${ }^{2}$, Cifang $\mathrm{Wu}^{1}$, Hongyu Zheng ${ }^{3,4}$

${ }^{1}$ School of Public Affairs, Zhejiang University, Hangzhou, China

${ }^{2}$ Department of Civil, Geo and Environmental Engineering, Technische Universität München, München, Germany

${ }^{3}$ School of Politics and Public Administration, Soochow University, Suzhou, Jiangsu, China

${ }^{4}$ Collaborative Innovation Center for New-type Urbanization and Social Governance, Soochow University, Suzhou, Jiangsu, China

Corresponding Author:

Guangyu Li and Cifang Wu

Yuhangtang Road, Hangzhou, 310058, China

Email address: 11422033@zju.edu.cn and wucifang@zju.edu.cn

\section{Abstract}

Fallow management can improve the soil nutrients in the topsoil and upper subsoil. However, little is known about the effects of short-term (one year) fallowing with different treatments, such as vegetation and fertilization, on subsoil $(20-40 \mathrm{~cm})$ properties. We conducted field trials to explore the changes in subsoil properties in response to such treatments in the Yellow River Delta region in China. Different vegetation and fertilization treatments were applied, and we measured the carbon and nitrogen contents, microbial biomass and microbial community structure in the subsoil.

Fallowing without manure resulted in the storage of more total nitrogen $(16.38 \%)$ than fallowing with manure, and meadow vegetation improved the ammonium nitrogen content $(45.71 \%)$ relative to spontaneous vegetation. Spontaneous vegetation with manure improved the microbial biomass nitrogen $(\mathrm{P}<0.05)$. Although the impact of short-term fallowing on microbial community structure was low, an effect of management was observed for some genera. Blastopirellula, Lysobacter, and Acidobacteria Gp6 showed significant differences among fallow treatments by the end of the year $(\mathrm{P}<0.05)$. Blastopirellula 
33 abundance was related to the microbial biomass nitrogen and nitrogen mineralization rate in the subsoil.

34 Manure retained a high abundance of Lysobacter, which may strengthen soil-borne disease resistance.

35 The response of Acidobacteria Gp6 showed that meadow vegetation without manure may not benefit

36 future crops. Although the treatments did not significantly improve microbial community structure in the

37 one-year period, annual fallowing improved certain subsoil properties and increased the number of

38 functional genera, which may enhance crop productivity in the future.

\section{Introduction}

40 Agricultural fallowing is an effective method for restoring degenerated farmland (Akobundu et al. 1999;

41 Burgers et al. 2005; Manalil \& Flower 2014). However, long-term fallowing is usually used to increase

42 biodiversity protection and microclimate modulation rather than improve farmland fertility (Qiu et al.

43 2016). For example, the Chinese "Grain for Green" program has resulted in the extensive addition of

44 green cover in the past 20 years (Chen et al. 2019). However, an energy evaluation revealed increasing

45 chemical fertilizer input and agricultural pollution in northwestern China because the farmlands that did

46 not participate in the "Grain for Green" project were more profitable (Feng et al. 2005; Wang et al. 2014).

47 Based on these issues, an arable land fallow system (henceforth, the fallow system) was initiated in pilot

48 regions in 2016 (Reuters 2018; Wang et al. 2018). The purpose of the fallow system is to restore farmland

49 and improve agricultural productivity ( $\mathrm{Du} 2018$ ). The participating farmland will be used for food

50 production again after the fallow period.

51 Nutrient input is still necessary under fallow management (Gregory et al. 2016). Improved fallow systems

52 in Africa have also involved the addition of organic amendments to improve soil fertility, and maize

53 yields increased after the fallow period (Manyanga et al. 2014). According to some studies, plants

54 belonging to Fabales can improve soil quality and fallow efficiency by promoting nitrogen fixation

55 (Akobundu et al. 1999; Sileshi \& Mafongoya 2006; Wick et al. 1998). Existing studies lack a comparison

56 of fertilization and vegetation effects under fallow management, especially the possible interactions

57 between these factors. We attempted to establish different fallow practices based on vegetation and

58 fertilization. Mixed grass can support diverse soil microbial functions through the reciprocal action of

Peer] reviewing PDF | (2019:01:34545:3:0:NEW 6 Jul 2019) 
59 residue and soil heterotrophic microbial communities (Eisenhauer et al. 2010; Zak et al. 2003). A

60 previous study indicated that plant roots are the main substrates of subsoil microorganisms (Börjesson et

61 al. 2012).

62 Topsoil is more sensitive than other soil layers to biogeochemical processes (Ma et al. 2016);

63 consequently, studies of the topsoil (up to $20 \mathrm{~cm}$ ) in fallow areas are prevalent. A study of topsoil showed

64 that spontaneous fallow vegetation with fertilization improved soil microbial biomass nitrogen (MBN)

65 and some members of functional microbial communities, such as Nitrospira, Steroidobacter, and

66 Lysobacter (Li et al. 2018). In addition, subsoil also plays a crucial role in agroecosystems. Subsoil

67 (below $20 \mathrm{~cm}$ ) can provide nutrient elements to crop roots and can be primed by the addition of fertilizer,

68 which causes $\mathrm{N}$ and C loss (Heitkötter et al. 2017; Kautz et al. 2013). In fallow studies, subsoil is

69 considered only in the case of subsoil remediation and when comparing soil layers (Chintu et al. 2004;

70 Gill et al. 2012; Gregory et al. 2016). Subsoiling, which is a general tillage method in northern China (He

71 et al. 2019), will be applied in our study farmlands. Therefore, it is necessary to study the subsoil to

72 improve the soil quality.

73 Compared with topsoil, which is more sensitive, subsoil is often ignored in the fallow practices. In fact, a

74 long-term study (fifteen years) showed that subsoil could retain $20 \%$ of total carbon from amendments

75 (Kätterer et al. 2014). Fallow vegetation impacts nitrification in subsoil over a short time period (15

76 months). The nitrate nitrogen content under Sesbania fallowing was greater than that under natural

77 fallowing because of the nitrogen mineralization of Sesbania (Mekonnen et al. 1997). Moreover, natural

78 fallowing and fallowing with maize litter (one year) resulted in more extractable nitrogen in the examined

79 soil layers $(0-40 \mathrm{~cm})$ than planted maize because of the high nitrogen utilization via enzymes in fallow

80 farmlands (Loeppmann et al. 2016). Soil carbon seems to be more stable than soil nitrogen. Therefore, the

81 impact of short-term fallowing may be reflected in upper subsoil nitrogen.

82 Organic amendments have little impact on microbial composition (Kätterer et al. 2014). A similar result was

83 also found in an exotic plant invasion study, in which microbial community structure was not significantly

84 affected by current vegetation and instead was largely determined by previous vegetation (Elgersma et al.

PeerJ reviewing PDF | (2019:01:34545:3:0:NEW 6 Jul 2019) 
85 2011). However, another study found that microbial biomass can be significantly improved by no-tillage and

86 residue in short-term conservation management practices (1 to 2 years) (Guo et al. 2015). A study on

87 fertilization showed that Bacillus sp. was promoted by organic manure in one year (Zhang et al. 2015). A study

88 on the use of organic fertilizer for soil remediation found that the fertilizer altered some soil microbial

89 communities in a short period ( 2 months) by altering the characteristics and improving the water-holding

90 capacity of the soil which could be a benefit for shaping microbial community composition (Chessa et al.

91 2016; Wang et al. 2018).

92 In a long-term fallowing study, fallow farmlands maintained microbial biomass carbon (MBC) in

93 different soil layers $(0-30 \mathrm{~cm})$, and MBN in the topsoil $(0-20 \mathrm{~cm})$ because fallowing improves soil

94 structure and protects the integrity of fungal hyphae. Simultaneously, microbial biomass depends on the

95 available nutrients (Qiu et al. 2016). Based on the above findings, plants and farmyard manure can

96 promote the availability of soil nutrients. The impact of organic manure on microbial compositions occurs

97 over a short period of time. However, the impact may be high in the initial period and decrease with fertilizer

98 consumption. The soil microbial diversity and community structure may not change significantly in a short

99 period of time. Regardless, some microbial communities, such as heterotrophic bacteria, will present

100 continuous alterations. We hypothesize that the application of mixed plants and farmyard manure will

101 accelerate changes in subsoil nitrogen, microbial biomass nutrients and some bacterial communities under

102 short-term fallow management. To determine the impact of short-term fallowing on subsoil, we planned a

103 five-year field trial in a Chinese agricultural region and intended to analyze changes in the soil

104 environment and microbial community in the first, third and fifth years. In this study, the results from the

105 first year are reported. To accurately study the changes in microbiota, we considered separate seasons,

106 including the initial stage, flourishing stage, and resting stage (June, August, and October, respectively).

107 Based on relevant studies, we believe that microbial composition is generally used to assess the carbon-

108 nitrogen cycle, soil-borne disease resistance and crop productivity in agricultural management (Filip

109 2002; Lammel et al. 2015). In terms of long-term fallow management, analysis of soil microbial

110 community structure and physicochemical properties has been used as a reliable method for explaining

PeerJ reviewing PDF | (2019:01:34545:3:0:NEW 6 Jul 2019) 
111 the ecological processes in agroecosystems (Hamer \& Makeschin 2009; Hamer et al. 2008; Kätterer et al.

112 2014). Therefore, DNA analysis can be used as a precise taxonomical method to analyze soil microbial

113 community structure.

\section{Materials \& Methods}

115 2.1. Study Site

116 The research area is located at the Shandong Wudi Field Scientific Observation \& Research Base for

117 Land Use in Binzhou, China [E $117^{\circ} 43^{\prime}, \mathrm{N} 37^{\circ} 48^{\prime}$, at an altitude of $5 \mathrm{~m}$ above sea level (a.s.l)]. The

118 rainfall ranges from $0 \mathrm{~mm}$ to $421.8 \mathrm{~mm}$, with a 10 -year average of $55.3 \mathrm{~mm}$. The average temperature is

$11913.9^{\circ} \mathrm{C}$, varying between $-6.1^{\circ} \mathrm{C}$ and $28.4{ }^{\circ} \mathrm{C}$ (Figure S1). Having a silty loam texture (approximately

$1203 \%$ clay and $78 \%$ silt), the study soil stemmed from diluvial sediments and is classified as a typical saline

121 alluvial soil (Fluvisols, FAO). An investigation by local agricultural institutions revealed that sorghum

122 [Sorghum bicolor (L.) Moench] monoculture was practiced for more than 5 years in our study area, and

123 soil fertility has decreased markedly in the study area according to a relevant study (Lv 2018). The survey

124 revealed that some farmlands (45\%) around the study sites were already unmanaged, planted with other

125 crops or rebuilt as artificial lakes, and these could be found on the map (Liu 2014). Before the

126 experiment, the farmlands were compacted by a four-wheeled tractor which is a common practice after

127 harvest. From 2010 to 2015 , the same arable land management scheme was applied to experimental plots.

128 2.2. Experimental Design

129 The experiment started in May 2016, and the study fields were flat and consisted of uniform features. The 130 chemical properties of the subsoil (20-40 cm layer) were as follows: electrical conductivity of $2.0 \mu \mathrm{S} \mathrm{m}^{-1}$, 131 total nitrogen (TN) content of $0.52 \mathrm{mg} \mathrm{g}^{-1}$, soil organic carbon content (SOC) of $3.39 \mathrm{mg} \mathrm{g}^{-1}$, available 132 nitrogen content of $20.59 \times 10^{-3} \mathrm{mg} \mathrm{g}^{-1}$, available potassium (AK) content of $0.16 \times 10^{-3} \mathrm{mg} \mathrm{g}^{-1}$, available 133 phosphorus (AP) content of $2.11 \times 10^{-3} \mathrm{mg} \mathrm{g}^{-1}$, and a $\mathrm{pH}$ of 8.90 . The data were provided by local 134 agricultural sectors.

135 We established four treatments in the study area. The total area of our experimental zone was 2 ha. There 136 were four parallel plots per treatment, and three were selected for statistical analysis. The size of each plot 
137 was $5 \times 6 \mathrm{~m}$, and the plots were randomly distributed (spaced more than $1 \mathrm{~m}$ apart). We selected alfalfa

138 (Medicago sativa L.) and Dahurian wild rye (Elymus dahuricus Turcz.), which are found in the

139 indigenous meadow in the study area, to create plant mixtures to build meadows for fallowing without

140 manure fallow (NM) and with manure fallow (MM). We also examined the effects of fallowing with

141 natural regrowth of the spontaneous vegetation without manure fallow (NS) and with manure (MS). Then,

142 we performed fertilization with manure from local livestock; water must be mixed with cattle manure to

143 prevent hardening, and fertilization was accompanied by irrigation. Finally, no pesticides were used in

144 our study region.

145 Four fallow treatments were detailed as follows:

146 (i) NS, no manure input, no-tillage, and spontaneous vegetation fallowing, referred to as natural 147 fallowing;

148 (ii) NM, no manure input, minimum tillage (manual weeding) but sown with alfalfa (M. sativa) and Dahurian wild rye (E. dahuricus), referred to as meadow fallowing;

150 (iii) MS, no-tillage, natural fallowing with composted cattle manure (400 g kg-1 organic C, $7.0 \mathrm{~g} \mathrm{~kg}^{-1}$ $\mathrm{TN}, 11.5 \mathrm{~g} \mathrm{~kg}^{-1}$ total $\mathrm{P}$, and $9.8 \mathrm{~g} \mathrm{~kg}^{-1}$ total $\mathrm{K}$ ) applied at $1500 \mathrm{~kg} \mathrm{ha}^{-1}$; and

152 (iv) MM, minimum tillage, meadow fallowing (the plant cover same as in NM) with composted cattle manure (same as in MS) applied at $1500 \mathrm{~kg} \mathrm{ha}^{-1}$.

\section{2.3. Preparation of Soil Samples}

155 The first soil sampling occurred in June 2016. The second and third samplings were performed in August 156 and October 2016, respectively. We selected 3 plots from each treatment. Based on the "S" sampling 157 technique, subsoil samples were collected from 6 points at a depth of $20-40 \mathrm{~cm}$ in each plot; a foil 158 sampler was employed. The samples were then mixed and homogenized. Each soil sample was passed 159 through $\mathrm{a}<2 \mathrm{~mm}$ sieve to remove plant roots and stones and was then divided into three parts. The first 160 part was stored at $-20{ }^{\circ} \mathrm{C}$ prior to DNA analysis, and another part was stored at $4{ }^{\circ} \mathrm{C}$ for microbial

161 biomass analysis. The remainder was air dried to assay the soil physicochemical properties.

162 2.4. Soil Physical and Chemical Properties

PeerJ reviewing PDF | (2019:01:34545:3:0:NEW 6 Jul 2019) 
163 The soil $\mathrm{pH}$ was determined using a $\mathrm{pH}$ meter. The SOC content was determined using air-dried, finely

164 ground soil aliquots. Subsamples of $10 \mathrm{mg}$ each were weighed in a tin cap containing phosphoric acid and 165 analyzed with a CN analyzer (SOC-L Analyzer and SSM-5000A unit, Shimadzu, Japan). The TN was

166 assayed by the Kjeldahl method (Bremner et al. 1996). The carbon to nitrogen ratio (C/N) was calculated

167 based on the SOC and TN. Soil ammonium concentrations $\left(\mathrm{NH}_{4}^{+}-\mathrm{N}\right)$ in each sample were analyzed via a

168 continuous flow analyzer (Skalar San Plus automated wet chemistry analyzer, Breda, the Netherlands).

169 2.5. Biological Analysis

170 2.5.1. Soil Microbial Biomass

171 The soil MBC and MBN were determined in accordance with the fumigation-extraction method (Brookes

172 et al. 1985; Vance et al. 1987). For each study plot, three of six subsamples (each consisting of $10.0 \mathrm{~g}$ of

173 fresh soil stored at $4{ }^{\circ} \mathrm{C}$; the remaining three were blank controls) were fumigated with ethanol-free

174 chloroform for $24 \mathrm{~h}$ at $25^{\circ} \mathrm{C}$ in an evacuated extractor (a vessel). The remaining samples were considered

175 controls. All fumigated and non-fumigated soil samples were extracted with $40 \mathrm{~mL}$ of $0.5 \mathrm{M} \mathrm{K}_{2} \mathrm{SO}_{4}$ (soil:

$176 \mathrm{~K}_{2} \mathrm{SO}_{4}$ solution $\left.=1: 4\right)$ and shaken for $1 \mathrm{~h}$ on a reciprocal shaker. The extracts were filtered using Whatman

177 No.42 filter papers with a $7 \mathrm{~cm}$ diameter and stored frozen at $-15^{\circ} \mathrm{C}$ prior to analysis. The carbon and

178 nitrogen in the extracts were measured by a Multi N/C 3000 Analyzer (Elementar Analysensysteme

$179 \mathrm{GmbH}$, Langenselbold, Germany).

180 The MBC was calculated as follows:

$181 \mathrm{MBC}=\mathrm{EC} / \mathrm{k}_{\mathrm{EC}}$

182 where $\mathrm{EC}=($ organic carbon extracted from fumigated soils $)$ - (organic carbon extracted from

183 nonfumigated soils) and $\mathrm{k}_{\mathrm{EC}}=0.3$ (Joergensen 1996).

184 The MBN was calculated as follows:

$185 \mathrm{MBN}=\mathrm{EN} / \mathrm{k}_{\mathrm{EN}}$

186 where $\mathrm{EN}=($ total nitrogen extracted from fumigated soils $)$ - (total nitrogen extracted from nonfumigated 187 soils) and $\mathrm{k}_{\mathrm{EN}}=0.45$ (Joergensen 1996). 
188 Finally, the microbial biomass carbon to nitrogen ratio (MBC/MBN) was calculated based on the MBC 189 and MBN.

190 2.5.2. DNA Extraction and MiSeq Illumina Sequencing

191 The total soil genomic DNA was extracted from $0.25 \mathrm{~g}$ of each soil sample using a FastDNA kit (MoBio

192 Labs, Solana Beach, USA). The DNA concentration and quality were checked using a NanoDrop

193 Spectrophotometer (NanoDrop Technologies Inc., Wilmington, USA). The extracted DNA was diluted to $19410 \mathrm{ng} \mu \mathrm{L}^{-1}$ and stored at $-20^{\circ} \mathrm{C}$ for downstream analysis.

195 The primer pair 515F (5'- GTGCCAGCMGCCGCGG -3') and reverse primer 907R (5'-

196 CCGTCAATTCMTTTRAGTT-3') with a unique 6-nt barcode were used to amplify the hypervariable V4 197 region of the $16 \mathrm{~S}$ rRNA gene (Angenent et al. 2005). The PCR mixture ( $25 \mu \mathrm{L}$ ) contained 1x PCR buffer, $1981.5 \mathrm{mM} \mathrm{MgCl}_{2}$, each deoxynucleoside triphosphate at $0.4 \mathrm{mM}$, each primer at $1.0 \mathrm{mM}, 0.5 \mathrm{U}$ of Ex Taq 199 (TaKaRa, Dalian) and 10 ng of soil genomic DNA. The PCR amplification program included an initial 200 denaturation at $94{ }^{\circ} \mathrm{C}$ for $3 \mathrm{~min}$, followed by 30 cycles of $94{ }^{\circ} \mathrm{C}$ for $40 \mathrm{~s}, 56^{\circ} \mathrm{C}$ for $60 \mathrm{~s}$, and $72{ }^{\circ} \mathrm{C}$ for 60 $201 \mathrm{~s}$, and a final extension at $72{ }^{\circ} \mathrm{C}$ for $10 \mathrm{~min}$. Three replicate PCR products for each sample were combined 202 and loaded in 1.0\% agarose gel electrophoresis. The band with the correct size was excised and purified 203 using the TaKaRa MiniBEST Agarose Gel DNA Extraction Kit (TaKaRa, Dalian) and quantified with a 204 NanoDrop. All samples were pooled together, with equal molar amounts from each sample. The 205 sequencing samples were prepared using the TruSeq DNA Kit according to the manufacturer's 206 instructions. The purified library was diluted, denatured, rediluted, mixed with PhiX (equal to $30 \%$ of the 207 final DNA amount) as described in the Illumina library preparation protocols, and then applied to an 208 Illumina Miseq system for sequencing with the Reagent Kit v2 $2 \times 250 \mathrm{bp}$ as described in the 209 manufacturer's manual.

210 2.5.3. Sequencing Data Processing

211 The processing of the raw sequences obtained through Illumina sequencing was performed using the 212 Quantitative Insights into Microbial Ecology (QIIME) pipeline (Caporaso et al. 2010). We assembled 213 paired-end reads using FLASH (Magoč \& Salzberg 2011). Reads with quality score lower than 20, 
214 ambiguous bases and improper primers were discarded before clustering. The resultant high-quality 215 sequences were subsequently clustered into operational taxonomic units (OTUs) at 97\% similarity using 216 the UPARSE algorithm (Edgar 2013). Simultaneously, chimeras were checked and eliminated during 217 clustering. Taxonomic classification of representative sequences from individual OTUs was performed 218 using the Ribosomal Database Project (RDP version 2.12) Classifier (Wang et al. 2007). To compare the 219 relative difference between samples, a randomly selected subset of 8260 sequences per sample was used 220 for downstream analyses.

2212.6 Statistical Analysis

222 Analysis of variance (ANOVA), principal component analysis (PCA), and Spearman's rank test were 223 performed with SPSS software (version 13.0). Repeated-measures ANOVA (RMANOVA) was employed 224 to determine the effects of sampling time and fallowing management. Then, PCA was used to analyze the 225 soil physicochemical properties for each time. There were 6 soil variables in the PCA, and the C/N and $226 \mathrm{MBC} / \mathrm{MBN}$ were not included in the PCA. Two-way ANOVA was used to identify the effect of 227 fertilization and vegetation at each sampling date. Downstream statistical analysis of soil DNA was 228 performed using QIIME and R (R Core Team 2013). Alpha diversity indices were calculated in QIIME. 229 Bray-Curtis distance metrics were used to implement nonmetric multidimensional scaling (NMDS) with 230 monoMDS in the vegan package in R. Permutational multivariate ANOVA (PERMANOVA) was 231 employed to test for dissimilarity among fallow treatments with adonis in the vegan package in R (Frost 232 et al. 2018). The contribution of fallow treatments was graphed via a Venn diagram with systemPipeR in $233 \mathrm{R}$. The effects of fallow practices on dominant genera in different months were also determined by two234 way ANOVA. The correlations between soil characteristics and the predominant genera were estimated 235 via Spearman's rank test. The distribution of all soil physicochemical data at time level was non-normal; 236 therefore, we used the Spearman's rank test to ensure the reliability of the results.

\section{Results}

238 3.1. Physiochemical Characteristics and Microbial Biomass in Subsoil 
239 The RMANOVA showed that the impacts of sampling date were always significant and stronger than the

240 impacts of fallowing management (Table S1). Therefore, it was necessary to analyze the impact of

241 fallowing managements at each sampling time. The soil physiochemical properties were impacted by

242 different fallow practices. According to the PCA, the impact of treatment was low in June (Figure 1).

243 Beginning in August, differences between MM and spontaneous vegetation fallowing (MS and NS) were

244 observed. In October, only NS and NM overlap, and MS and MM do not overlap with other treatments.,

245 which indicated that the differences became larger.

246 Effects of the interaction between fertilization and vegetation appeared in August (Figure 2 and Table

247 S2). In August, the interaction had significant effects on TN, C/N, MBN, and MBC/MBN (two-way

248 ANOVA, $\mathrm{P}<0.05$ ). In October, cattle manure significantly increased the $\mathrm{pH}$ and $\mathrm{C} / \mathrm{N}$, while $\mathrm{TN}$

249 decreased significantly (two-way ANOVA, $\mathrm{F}=8.367, \mathrm{~F}=8.867$, and $\mathrm{F}=11.024$, respectively, $\mathrm{P}<0.05$ ).

250 Meadow vegetation significantly promoted $\mathrm{NH}_{4}{ }^{+} \mathrm{N}$ (two-way ANOVA, $\mathrm{F}=8.797, \mathrm{P}<0.05$ ). The

251 interaction between fertilization and vegetation had significant effects on MBN and MBC/MBN (two-way

252 ANOVA, $\mathrm{F}=17.742$ and $\mathrm{F}=28.149$, respectively, $\mathrm{P}<0.01)$.

253 3.2. Diversity of the Microbial Community in Subsoil

254 The alpha diversity indicators did not show any significant differences; therefore, we focused on the beta

255 diversity. NMDS revealed that the stress values increased from 0.0459 to 0.1065 , which indicated that the

256 differences became smaller (Figure 3). The changes in the microbial community structure in August were

257 different from those in June and October, which caused an increase in the stress value (Table S3). The

258 NMDS stress value of the combination of June and October microbial community structure was 0.074 ,

259 which indicated that the NMDS was efficient.

260 In June, microbial community structure was significantly influenced by the interactions between

261 fertilization and vegetation (PERMANOVA, $\mathrm{F}=2.979, \mathrm{P}<0.01$ ). However, the microbial community

262 was not affected by fertilizer or vegetation in August and October. Therefore, the influence of manure

263 gradually diminished under short-term fallowing (Table S4). Moreover, the Venn diagram showed that

PeerJ reviewing PDF | (2019:01:34545:3:0:NEW 6 Jul 2019) 
264 the manure strongly impacted microbial community structure in June. However, the differences became 265 smaller in October (Figure S2).

266 3.3. Microbial Communities in Subsoil

267 Each sample contained 34 bacterial phyla. October was the time period with the smallest difference at the 268 phylum level (Figure 4C). Acidobacteria Gp6, Acidobacteria Gp4, Gemmatimonas, Luteimonas, and 269 Lysobacter increased in abundance in October (Figure 4A). According to Figure 4B and Figure S3, 270 Acidobacteria Gp10, Gaiella, Sphaerobacter, Nitrospira, Blastopirellula, Geminicoccus, Ramlibacter, 271 and Lysobacter were all impacted by the interaction between fertilization and vegetation in June (two-way 272 ANOVA, $\mathrm{P}<0.05$ ). In October, the impact of manure on Lysobacter reappeared again (two-way 273 ANOVA, $\mathrm{F}=10.904, \mathrm{P}<0.05)$. In addition, Acidobacteria $G p 6$ was impacted by the interaction, and 274 Blastopirellula was still impacted by vegetation (two-way ANOVA, $\mathrm{F}=8.573$ and $\mathrm{F}=6.084$, 275 respectively, $\mathrm{P}<0.05)$.

276 3.4. The Relationship Between Physicochemical Properties and Microbial Communities

277 We selected Acidobacteria Gp6, Blastopirellula, and Lysobacter for analysis because their abundances 278 were significantly impacted by the treatments after annual fallowing. Acidobacteria Gp6 showed a 279 negative correlation with soil $\mathrm{pH}$ (Spearman's rank test, rho $=-0.632, \mathrm{P}<0.001$ ) (Table 1).

280 Blastopirellula showed a positive correlation with MBN and a negative correlation with MBC/MBN 281 (Spearman's rank test, rho $=0.485$ and rho $=-0.357$, respectively, $\mathrm{P}<0.05$ ). Lysobacter showed a 282 negative correlation with $\mathrm{pH}$ and SOC (Spearman's rank test, rho $=-0.483$ and rho $=-0.359$, respectively, $283 \mathrm{P}<0.05)$.

\section{Discussion}

285 According to previous studies, short-term fallow management impacts extractable nitrogen but does not 286 significantly alter the soil carbon and microbial community structure. In our study, $\mathrm{TN}, \mathrm{NH}_{4}^{+}-\mathrm{N}$, and 287 MBN were impacted by vegetation and fertilization. Microbial community structure was stable, consistent 288 with the findings of previous studies. In addition, some bacterial genera changed in response to vegetation 
and fertilization. The differences in soil properties among the sampling dates were significant. Therefore,

290 we discussed the impact of fallowing treatments at different sampling times.

291 Based on the PCA, the impact of fertilization and vegetation on subsoil physicochemical properties lasted

292 from the growth season (August) to the end of the fallow period. Cattle manure increased the $\mathrm{pH}$ in

293 October, in accordance with previous studies (Li et al. 2018), which may limit the growth of some

294 microorganisms. The impact of fallow conditions on carbon was nonsignificant, in accordance with a

295 previous study (Loeppmann et al. 2016). The effects of spontaneous grass with manure on TN were

296 significant beginning in August. Based on a previous study, cattle manure can increase the diversity and

297 abundance of spontaneous grasses (Materechera \& Modiakgotla 2006). Competition among spontaneous

298 grasses occurred because of manure input (Rajaniemi 2002). Some grasses that were present before

299 manure input died and became a source of nutrients at the flourishing stage. The flourishing plant roots in

300 the topsoil and subsoil resulted in high total nitrogen in MS (Figure S4). In October, the dominant grasses

301 were already present and continued to grow; consequently, they required more total nitrogen, resulting in

302 decreased total nitrogen in MS. The changes in C/N were caused by TN in June and August. In June, the

$303 \mathrm{C} / \mathrm{N}$ was sensitive to vegetation because alfalfa planting can reduce the growth of deep roots of weeds,

304 which consume nitrogen in the subsoil (Forney et al. 1985; Ominski et al. 1999). However, the effects of

305 fertilization replaced the vegetation present in October. The amount of $\mathrm{TN}$ and $\mathrm{C} / \mathrm{N}$ indicated that

306 fallowing without manure could save more TN. This finding is different from that of a previous study, in

307 which manure increased the TN content (Hao et al. 2003). This result may be due to the insufficient

308 application of fertilizer and a decrease in the subsoil TN content because of vegetation assimilation

309 (Mooleki et al. 2004). Based on the changes in ammonium nitrogen, our result is similar to a previous

310 study reported by Schroth et al. (1999). The mineral nitrogen also decreased in response to spontaneous

311 fallow vegetation, whereas the fallow treatments with alfalfa retained ammonium nitrogen.

$312 \mathrm{MBC}$ did not differ among treatments. In terms of $\mathrm{MBN}$ and $\mathrm{MBC} / \mathrm{MBN}$, the interaction significantly

313 impacted the MBN. The NM and MS showed that meadow vegetation without manure and spontaneous

314 vegetation with manure maintained more MBN. According to nitrogen consumption and a previous study, 
315 MBN is impacted by available nitrogen content and plant growth (Bell et al. 2010; Yao et al. 2011).

316 Therefore, manure allowed the spontaneous vegetation to maintain vigorous growth in October. As a

317 result, MS retained more MBN than NS. Alfalfa usually uptake more nitrogen than grass and the manure

318 can enhance the nitrogen assimilation (Jefferson et al. 2013). Thus, NM retained more nitrogen for the

319 soil microorganisms than MM.

320 The alpha diversity results indicated that the impact of treatments and time was not significant (Table S1).

321 The short-term fallow treatment did not significantly disturb the microbial community structure in the

322 subsoil, similar to the findings of a previous study (Bossio et al. 1998). Even though the beta diversity

323 also was nonsignificant, it indicated that the effects of fallow conditions on microbial composition

324 decreased with time, in contrast to the alteration of soil nutrients. Therefore, we conducted a more in-

325 depth analysis of the microbial communities.

326 The differences in bacterial phyla composition were also nonsignificant. However, the effect of

327

328

329

330

331

332

333

334

335

336

337

338

339 treatments on genera persisted. In terms of taxonomy, high-throughput sequencing can complement

previous studies that used the phospholipid fatty acid method (Orwin et al. 2018). More genera showed

significant differences in June than in August and October. Therefore, we found that fertilization and

vegetation can change some microbial communities in a short period of time (Chessa et al. 2016; Wang et

al. 2018). Then, a legacy effect can adjust the microbial composition (Elgersma et al. 2011). However,

some genera continued to change after fallow management. We focused on these genera.

The proportion of Acidobacteria Gp6 increased in all treatments by the end of the year, and the highest

abundance was observed in NS in October. A previous study showed that Acidobacteria Gp6 was

negatively related to $\mathrm{pH}$ under saline-alkaline conditions (Cui et al. 2018), which was confirmed in our study. Therefore, the abundance of Acidobacteria Gp6 was relatively low under fallow conditions with manure (MS and MM). However, Acidobacteria Gp6 presented a significantly lower abundance in NM than in NS. We assume that the lower carbon and nitrogen contents may have caused the decrease in Acidobacteria Gp6 abundance in NM (Sul et al. 2013). Notably, Acidobacteria Gp6 plays an important

PeerJ reviewing PDF | (2019:01:34545:3:0:NEW 6 Jul 2019) 
340 role in plant growth (Tao et al. 2018). The lower Acidobacteria Gp6 abundance implied that the NM may

341 not promote crop yields in the future.

342 Blastopirellula was consistently impacted by fallow management throughout the experiment.

343 Blastopirellula is a heterotrophic bacterium that originates from seawater, requires an alkaline

344 environment and uses $N$-acetylglucosamine as a carbon and nitrogen source (Schlesner 2015). Based on

345 the correlation analysis, we believe that the nitrogen source strongly impacted the genus. According to the

346 fate of chitin degradation, chitin can be transformed to $N$-acetylglucosamine and then to MBN (Beier \&

347 Bertilsson 2013). The proportion of Blastopirellula may reflect the nitrogen content and mineralization in

348 different fallow treatments. The genus was impacted by the meadow vegetation in October. Based on the

349 changes in ammonium nitrogen, we concluded that the meadow vegetation increased the efficiency of

350 nitrogen mineralization, which produced a nitrogen source for Blastopirellula (Sun et al. 2017). The

351 abundance in MS was relatively higher than that in NS, which indicated that manure alleviated the

352 deficiency of indigenous grass. Cow manure provided chitin as a nitrogen source, as mentioned in a

353 previous study (Labrie et al. 2001).

354 Lysobacter increased in response to manure addition by the end of the fallow period. Some strains of

355 Lysobacter are related to plant disease resistance (Ji et al. 2008; Kilic-Ekici \& Yuen 2004). Lysobacter

356 can survive in saline soil, and it was negatively associated with pH in our study (Ma \& Gong 2013;

357 Siddiqi \& Im 2016). The reason for this association may be that the $\mathrm{pH}$ in our study area exceeded the

358 optimum value allowing survival of Lysobacter, which is 8.0 or 7.5 (Park et al. 2008; Weon et al. 2007).

359 However, our results indicated that fertilization simultaneously increased $\mathrm{pH}$ and the proportion of

360 Lysobacter in October because the $\mathrm{pH}$ of all treatments slightly decreased in October. The $\mathrm{pH}$ limitation

361 was alleviated. We believe that cattle manure can have long-term effects on Lysobacter, similar to the

362 findings of previous studies ( $\mathrm{Li}$ et al. 2018; Soman et al. 2017). Therefore, fallow conditions with manure 363 may increase disease suppression in the subsoil. 
364 In summary, the results support our hypothesis. The short-term fallow management practices impacted 365 subsoil nitrogen, MBN and microbial communities. In addition, the microbial community structure did 366 not change significantly. The effects of fallow practices on subsoil are as follows:

367 1) Manure had significant effects on soil characteristics ( $\mathrm{pH}, \mathrm{TN}$ content, and $\mathrm{C} / \mathrm{N}$ ) and Lysobacter, 368 which are related to disease resistance. Manure addition increased subsoil $\mathrm{C} / \mathrm{N}$ and $\mathrm{pH}$. Without 369 manure, more nitrogen was stored in the subsoil, decreasing the $\mathrm{pH}$.

370 2) Meadow vegetation (alfalfa and Dahurian wild rye) mainly affected nitrogen transformation.

371 Compared with spontaneous vegetation, meadow vegetation improved nitrogen mineralization, which 372 was also shown by the changes in Blastopirellula.

373 3) The combination of manure and meadow vegetation did not provide more benefits than either of these treatments applied individually. Spontaneous vegetation without manure increased the abundance of Acidobacteria Gp6, and spontaneous grass with manure increased MBN. Meadow vegetation with manure stored ammonium nitrogen. Meadow vegetation without manure decreased the abundance of Acidobacteria Gp6, which may not benefit crop yields. In general, spontaneous vegetation with manure was the most beneficial treatment.

\section{Conclusions}

380 Although this study showed that fallow practices did not significantly disturb the subsoil microbiota in the 381 first year, the different management practices still affected the soil physicochemical properties, especially nitrogen. Fallowing without manure is a good method for improving total nitrogen accumulation in the subsoil; however, the addition of manure improves the soil disease resistance. Additionally, fallowing with meadow vegetation promoted nitrogen mineralization. Nevertheless, the combination of meadow vegetation and manure was not optimal. If we wish to improve crop productivity via soil fertility and superiority in the next year, NS and MS may be helpful methods. If the quality of target farmland is not significantly degraded, MM can be used to promote soil sustainability and will result in some pasture subsoil environment in more detail. 
390

391

392

393

394

395

396

397

398

399

400

401

402

403

404

405

406

407

408

409

410

411

412

413

414

415

416

417

418

419

420

421

422

423

424

425

426

427

428

429

430

431

432

433

\section{Acknowledgments}

We are grateful for the support of the Binzhou Land Improvement and Remediation Engineering

Technology Research Center and to all colleagues who provided assistance.

\section{References}

Akobundu, Ekeleme, and Chikoye. 1999. Influence of fallow management systems and frequency of cropping on weed growth and crop yield. Weed Research 39:241-256. 10.1046/j.1365-3180.1999.00141.x Angenent LT, Kelley ST, Amand AS, Pace NR, and Hernandez MT. 2005. Molecular identification of potential pathogens in water and air of a hospital therapy pool. Proceedings of the National Academy of Sciences of the United States of America 102:4860-4865. 10.1073/pnas.0501235102

Beier S, and Bertilsson S. 2013. Bacterial chitin degradation-mechanisms and ecophysiological strategies. Frontiers in Microbiology 4. 10.3389/fmicb.2013.00149

Bell TH, Klironomos JN, and Henry HAL. 2010. Seasonal Responses of Extracellular Enzyme Activity and Microbial Biomass to Warming and Nitrogen Addition. 74:820-828. 10.2136/sssaj2009.0036 Börjesson G, Menichetti L, Kirchmann H, and Kätterer T. 2012. Soil microbial community structure affected by 53 years of nitrogen fertilisation and different organic amendments. Biology and Fertility of Soils 48:245-257. 10.1007/s00374-011-0623-8

Bossio DA, Scow KM, Gunapala N, and Graham KJ. 1998. Determinants of Soil Microbial Communities: Effects of Agricultural Management, Season, and Soil Type on Phospholipid Fatty Acid Profiles. Microbial Ecology 36:1-12. 10.1007/s002489900087

Bremner J, Sparks D, Page A, Helmke P, Loeppert R, Soltanpour P, Tabatabai M, Johnston C, and Sumner M. 1996. Nitrogen-total. Methods of soil analysis Part 3-Chemical methods:1085-1121. Brookes PC, Landman A, Pruden G, and Jenkinson DS. 1985. Chloroform fumigation and the release of soil nitrogen: A rapid direct extraction method to measure microbial biomass nitrogen in soil. Soil Biology and Biochemistry 17:837-842. http://dx.doi.org/10.1016/0038-0717(85)90144-0

Burgers P, Ketterings QM, and Garrity DP. 2005. Fallow management strategies and issues in Southeast Asia. Agriculture, Ecosystems Environment 110:1-13. https://doi.org/10.1016/j.agee.2005.04.010 Caporaso JG, Kuczynski J, Stombaugh J, Bittinger K, Bushman FD, Costello EK, Fierer N, Peña AG, Goodrich JK, Gordon JI, Huttley GA, Kelley ST, Knights D, Koenig JE, Ley RE, Lozupone CA, McDonald D, Muegge BD, Pirrung M, Reeder J, Sevinsky JR, Turnbaugh PJ, Walters WA, Widmann J, Yatsunenko T, Zaneveld J, and Knight R. 2010. QIIME allows analysis of high-throughput community sequencing data. Nature Methods 7:335. 10.1038/nmeth.f.303

https://www.nature.com/articles/nmeth.f.303\#supplementary-information Chen C, Park T, Wang X, Piao S, Xu B, Chaturvedi RK, Fuchs R, Brovkin V, Ciais P, Fensholt R, Tømmervik H, Bala G, Zhu Z, Nemani RR, and Myneni RB. 2019. China and India lead in greening of the world through land-use management. Nature Sustainability 2:122-129. 10.1038/s41893-019-0220-7 Chessa L, Pusino A, Garau G, Mangia NP, and Pinna MV. 2016. Soil microbial response to tetracycline in two different soils amended with cow manure. Environmental Science and Pollution Research 23:5807-5817. 10.1007/s11356-015-5789-4

Chintu R, Mafongoya PL, Chirwa TS, Mwale M, and Matibini J. 2004. SUBSOIL NITROGEN DYNAMICS AS AFFECTED BY PLANTED COPPICING TREE LEGUME FALLOWS IN EASTERN ZAMBIA. Experimental Agriculture 40:327-340. 10.1017/S0014479704001826

PeerJ reviewing PDF | (2019:01:34545:3:0:NEW 6 Jul 2019) 
434 Cui J, Li Y, Wang C, Kim KS, Wang T, and Liu S. 2018. Characteristics of the rhizosphere bacterial

435

436

437

438

439

440

441

442

443

444

445

446

447

448

449

450

451

452

453

454

455

456

457

458

459

460

461

462

463

464

465

466

467

468

469

470

471

472

473

474

475

476

477

478

479

480

481

482

483 community across different cultivation years in saline-alkaline paddy soils of Songnen Plain of China. Canadian Journal of Microbiology 64:925-936. 10.1139/cjm-2017-0752

$\mathrm{Du}$ Y. 2018. China's pilot crop rotation and fallow systems to facilitate green agri-culture. Available at http://en.people.cn/n3/2018/0313/c90000-9436320.html.

Edgar RC. 2013. UPARSE: highly accurate OTU sequences from microbial amplicon reads. Nature

Methods 10:996. 10.1038/nmeth.2604

https://www.nature.com/articles/nmeth.2604\#supplementary-information

Eisenhauer N, Beßler H, Engels C, Gleixner G, Habekost M, Milcu A, Partsch S, Sabais ACW, Scherber

C, Steinbeiss S, Weigelt A, Weisser WW, and Scheu S. 2010. Plant diversity effects on soil

microorganisms support the singular hypothesis. Ecology 91:485-496. doi:10.1890/08-2338.1

Elgersma KJ, Ehrenfeld JG, Yu S, and Vor T. 2011. Legacy effects overwhelm the short-term effects of exotic plant invasion and restoration on soil microbial community structure, enzyme activities, and nitrogen cycling. Oecologia 167:733-745. 10.1007/s00442-011-2022-0

Feng Z, Yang Y, Zhang Y, Zhang P, and Li Y. 2005. Grain-for-green policy and its impacts on grain supply in West China. Land Use Policy 22:301-312. http://dx.doi.org/10.1016/j.landusepol.2004.05.004

Filip Z. 2002. International approach to assessing soil quality by ecologically-related biological

parameters. Agriculture, Ecosystems Environment 88:169-174. http://dx.doi.org/10.1016/S01678809(01)00254-7

Forney DR, Foy CL, and Wolf DD. 1985. Weed Suppression in No-Till Alfalfa (Medicago sativa) by Prior Cropping of Summer-Annual Forage Grasses. Weed Science 33:490-497.

10.1017/S0043174500082710

Frost F, Kacprowski T, Rühlemann MC, Franke A, Heinsen F-A, Völker U, Völzke H, Aghdassi AA, Mayerle J, Weiss FU, Homuth G, and Lerch MM. 2018. Functional abdominal pain and discomfort (IBS) is not associated with faecal microbiota composition in the general population. Gut.

Gill JS, Clark GJ, Sale PW, Peries RR, and Tang C. 2012. Deep placement of organic amendments in dense sodic subsoil increases summer fallow efficiency and the use of deep soil water by crops. Plant and Soil 359:57-69. 10.1007/s11104-012-1126-6

Gregory AS, Dungait JAJ, Watts CW, Bol R, Dixon ER, White RP, and Whitmore AP. 2016. Long-term management changes topsoil and subsoil organic carbon and nitrogen dynamics in a temperate agricultural system. European Journal of Soil Science 67:421-430. 10.1111/ejss.12359

Guo L-J, Zhang Z-S, Wang D-D, Li C-F, and Cao C-G. 2015. Effects of short-term conservation management practices on soil organic carbon fractions and microbial community composition under a rice-wheat rotation system. Biology and Fertility of Soils 51:65-75. 10.1007/s00374-014-0951-6 Hamer U, and Makeschin F. 2009. Rhizosphere soil microbial community structure and microbial activity in set-aside and intensively managed arable land. Plant and Soil 316:57-69. 10.1007/s11104-008-9758-2 Hamer U, Makeschin F, Stadler J, and Klotz S. 2008. Soil organic matter and microbial community structure in set-aside and intensively managed arable soils in NE-Saxony, Germany. Applied Soil Ecology 40:465-475. http://dx.doi.org/10.1016/j.apsoil.2008.07.001

Hao X, Chang C, Travis GR, and Zhang F. 2003. Soil carbon and nitrogen response to 25 annual cattle manure applications. Journal of Plant Nutrition and Soil Science 166:239-245. 10.1002/jpln.200390035 He J, Shi Y, and Yu Z. 2019. Subsoiling improves soil physical and microbial properties, and increases yield of winter wheat in the Huang-Huai-Hai Plain of China. Soil and Tillage Research 187:182-193. https://doi.org/10.1016/j.still.2018.12.011

Heitkötter J, Heinze S, and Marschner B. 2017. Relevance of substrate quality and nutrients for microbial C-turnover in top- and subsoil of a Dystric Cambisol. Geoderma 302:89-99.

https://doi.org/10.1016/j.geoderma.2017.04.029

Jefferson PG, Selles F, Zentner RP, Lemke R, and Muri RB. 2013. Barley yield and nutrient uptake in rotation after perennial forages in the semiarid prairie region of Saskatchewan. Canadian Journal of Plant Science 93:809-816. 10.4141/cjps2013-069

PeerJ reviewing PDF | (2019:01:34545:3:0:NEW 6 Jul 2019) 
484 Ji G-H, Wei L-F, He Y-Q, Wu Y-P, and Bai X-H. 2008. Biological control of rice bacterial blight by

485

486

487

488

489

490

491

492

493

494

495

496

497

498

499

500

501

502

503

504

505

506

507

508

509

510

511

512

513

514

515

516

517

518

519

520

521

522

523

524

525

526

527

528

529

530

531

532

533
Lysobacter antibioticus strain 13-1. Biological Control 45:288-296.

https://doi.org/10.1016/j.biocontrol.2008.01.004

Joergensen RG. 1996. The fumigation-extraction method to estimate soil microbial biomass: Calibration of the kEC value. Soil Biology and Biochemistry 28:25-31. http://dx.doi.org/10.1016/0038-

0717(95)00102-6

Kätterer T, Börjesson G, and Kirchmann H. 2014. Changes in organic carbon in topsoil and subsoil and microbial community composition caused by repeated additions of organic amendments and $\mathrm{N}$

fertilisation in a long-term field experiment in Sweden. Agriculture, Ecosystems \& Environment 189:110118. https://doi.org/10.1016/j.agee.2014.03.025

Kautz T, Amelung W, Ewert F, Gaiser T, Horn R, Jahn R, Javaux M, Kemna A, Kuzyakov Y, Munch JC, Pätzold S, Peth S, Scherer HW, Schloter M, Schneider H, Vanderborght J, Vetterlein D, Walter A, Wiesenberg GLB, and Köpke U. 2013. Nutrient acquisition from arable subsoils in temperate climates: A review. Soil Biology and Biochemistry 57:1003-1022. https://doi.org/10.1016/j.soilbio.2012.09.014

Kilic-Ekici O, and Yuen GY. 2004. Comparison of strains of Lysobacter enzymogenes and PGPR for induction of resistance against Bipolaris sorokiniana in tall fescue. Biological Control 30:446-455.

https://doi.org/10.1016/j.biocontrol.2004.01.014

Labrie C, Leclerc P, Côté N, Roy S, Brzezinski R, Hogue R, and Beaulieu C. 2001. Effect of chitin wastebased composts produced by two-phase composting on two oomycete plant pathogens. Plant and Soil 235:27-34. 10.1023/A:1011807513547

Lammel D, Feigl B, Cerri C, and Nüsslein K. 2015. Specific microbial gene abundances and soil parameters contribute to $\mathrm{C}, \mathrm{N}$, and greenhouse gas process rates after land use change in Southern Amazonian Soils. Frontiers in Microbiology 6. 10.3389/fmicb.2015.01057

Li G, Wu C, and Gao W. 2018. Effects of short-term fallow managements on soil microbial properties: A case study in China. Applied Soil Ecology 125:128-137. https://doi.org/10.1016/j.apsoil.2017.12.005

Liu C. 2014. WUDI YEARBOOK. Beijing: CHINA LOCAL RECORDS PUBLISHING.

Loeppmann S, Blagodatskaya E, Pausch J, and Kuzyakov Y. 2016. Enzyme properties down the soil profile - A matter of substrate quality in rhizosphere and detritusphere. Soil Biology and Biochemistry 103:274-283. https://doi.org/10.1016/j.soilbio.2016.08.023

Lv K. 2018. Spatial and Temporal Variation of Soil Nutrients and Its Influencing Factors - A Case Study of Wudi County Master. Zhejiang University.

Ma B, and Gong J. 2013. A meta-analysis of the publicly available bacterial and archaeal sequence diversity in saline soils. World Journal of Microbiology and Biotechnology 29:2325-2334.

10.1007/s11274-013-1399-9

Ma B, Wang H, Dsouza M, Lou J, He Y, Dai Z, Brookes PC, Xu J, and Gilbert JA. 2016. Geographic patterns of co-occurrence network topological features for soil microbiota at continental scale in eastern China. ISME J 10:1891-1901. 10.1038/ismej.2015.261

Magoč T, and Salzberg SL. 2011. FLASH: fast length adjustment of short reads to improve genome assemblies. Bioinformatics 27:2957-2963. 10.1093/bioinformatics/btr507

Manalil S, and Flower K. 2014. Soil water conservation and nitrous oxide emissions from different crop sequences and fallow under Mediterranean conditions. Soil and Tillage Research 143:123-129.

http://dx.doi.org/10.1016/j.still.2014.06.006

Manyanga MA, Mafongoya PL, and Tauro TP. 2014. Soil macrofauna order diversity and abundance under improved fallows and organic matter transfer system in Zimbabwe. African Journal of Ecology 52:506-513. 10.1111/aje.12153

Materechera SA, and Modiakgotla LN. 2006. Cattle manure increases soil weed population and species diversity in a semi-arid environment. South African Journal of Plant and Soil 23:21-28.

$10.1080 / 02571862.2006 .10634725$

Mekonnen K, Buresh RJ, and Jama B. 1997. Root and inorganic nitrogen distributions in sesbania fallow, natural fallow and maize fields. Plant and Soil 188:319-327. 10.1023/A:1004264608576 
534

535

536

537

538

539

540

541

542

543

544

545

546

547

548

549

550

551

552

553

554

555

556

557

558

559

560

561

562

563

564

565

566

567

568

569

570

571

572

573

574

575

576

577

578

579

580

581

582

583

Mooleki SP, Schoenau JJ, Charles JL, and Wen G. 2004. Effect of rate, frequency and incorporation of feedlot cattle manure on soil nitrogen availability, crop performance and nitrogen use efficiency in eastcentral Saskatchewan. Canadian Journal of Soil Science 84:199-210. 10.4141/S02-045

Naether A, Foesel BU, Naegele V, Wüst PK, Weinert J, Bonkowski M, Alt F, Oelmann Y, Polle A, Lohaus G, Gockel S, Hemp A, Kalko EKV, Linsenmair KE, Pfeiffer S, Renner S, Schöning I, Weisser WW, Wells K, Fischer M, Overmann J, and Friedrich MW. 2012. Environmental factors affect acidobacterial communities below the subgroup level in grassland and forest soils. Applied and Environmental Microbiology. 10.1128/aem.01325-12

Ominski PD, Entz MH, and Kenkel N. 1999. Weed Suppression by Medicago sativa in Subsequent Cereal Crops: A Comparative Survey. Weed Science 47:282-290.

Orwin KH, Dickie IA, Holdaway R, and Wood JR. 2018. A comparison of the ability of PLFA and 16S rRNA gene metabarcoding to resolve soil community change and predict ecosystem functions. Soil Biology and Biochemistry 117:27-35. https://doi.org/10.1016/j.soilbio.2017.10.036

Park JH, Kim R, Aslam Z, Jeon CO, and Chung YR. 2008. Lysobacter capsici sp. nov., with antimicrobial activity, isolated from the rhizosphere of pepper, and emended description of the genus Lysobacter. International Journal of Systematic and Evolutionary Microbiology 58:387-392. doi:10.1099/ijs.0.65290-0

Qiu S, Gao H, Zhu P, Hou Y, Zhao S, Rong X, Zhang Y, He P, Christie P, and Zhou W. 2016. Changes in soil carbon and nitrogen pools in a Mollisol after long-term fallow or application of chemical fertilizers, straw or manures. Soil and Tillage Research 163:255-265. https://doi.org/10.1016/j.still.2016.07.002 R Core Team. 2013. R: A language and environment for statistical computing. Rajaniemi TK. 2002. Why does fertilization reduce plant species diversity? Testing three competitionbased hypotheses. Journal of Ecology 90:316-324. 10.1046/j.1365-2745.2001.00662.x Reuters. 2018. China to expand crop rotation and fallow systems trials. Available at https:/www.reuters.com/article/china-agriculture/china-to-expand-crop-rotation-and-fallow-systemstrials-idUSL4N1OX0PR.

Schlesner H. 2015. Blastopirellula. Bergey's Manual of Systematics of Archaea and Bacteria. Schroth G, da Silva LF, Seixas R, Teixeira WG, Macêdo JLV, and Zech W. 1999. Subsoil accumulation of mineral nitrogen under polyculture and monoculture plantations, fallow and primary forest in a ferralitic Amazonian upland soil. Agriculture, Ecosystems \& Environment 75:109-120. https://doi.org/10.1016/S0167-8809(99)00068-7

Siddiqi MZ, and Im W-T. 2016. Lysobacter hankyongensis sp. nov., isolated from activated sludge and Lysobacter sediminicola sp. nov., isolated from freshwater sediment. International Journal of Systematic and Evolutionary Microbiology 66:212-218. doi:10.1099/ijsem.0.000699

Sileshi G, and Mafongoya PL. 2006. Long-term effects of improved legume fallows on soil invertebrate macrofauna and maize yield in eastern Zambia. Agriculture, Ecosystems Environment 115:69-78. http://dx.doi.org/10.1016/j.agee.2005.12.010

Soman C, Li D, Wander MM, and Kent AD. 2017. Long-term fertilizer and crop-rotation treatments differentially affect soil bacterial community structure. Plant and Soil 413:145-159. 10.1007/s11104-0163083-y

Sul WJ, Asuming-Brempong S, Wang Q, Tourlousse DM, Penton CR, Deng Y, Rodrigues JLM, Adiku SGK, Jones JW, Zhou J, Cole JR, and Tiedje JM. 2013. Tropical agricultural land management influences on soil microbial communities through its effect on soil organic carbon. Soil Biology and Biochemistry 65:33-38. https://doi.org/10.1016/j.soilbio.2013.05.007

Sun G, Zhu-Barker X, Chen D, Liu L, Zhang N, Shi C, He L, and Lei Y. 2017. Responses of root exudation and nutrient cycling to grazing intensities and recovery practices in an alpine meadow: An implication for pasture management. Plant and Soil 416:515-525. 10.1007/s11104-017-3236-7

Tao J, Meng D, Qin C, Liu X, Liang Y, Xiao Y, Liu Z, Gu Y, Li J, and Yin H. 2018. Integrated network analysis reveals the importance of microbial interactions for maize growth. Applied Microbiology and Biotechnology 102:3805-3818. 10.1007/s00253-018-8837-4

Peer) reviewing PDF | (2019:01:34545:3:0:NEW 6 Jul 2019) 
584 Toivonen M, Herzon I, and Helenius J. 2013. Environmental fallows as a new policy tool to safeguard

585

586

587

588

589

590

591

592

593

594

595

596

597

598

599

600

601

602

603

604

605

606

607

608

609

610

611

612

613

614

615

616

617 farmland biodiversity in Finland. Biological Conservation 159:355-366. https://doi.org/10.1016/j.biocon.2012.11.016 Vance ED, Brookes PC, and Jenkinson DS. 1987. An extraction method for measuring soil microbial biomass C. Soil Biology and Biochemistry 19:703-707. https://doi.org/10.1016/0038-0717(87)90052-6 Wang C, Siriwardana M, and Meng S. 2018. Effects of the Chinese arable land fallow system and landuse change on agricultural production and on the economy. Economic Modelling. https://doi.org/10.1016/j.econmod.2018.10.012

Wang M, Chen L, Li Y, Chen L, Liu Z, Wang X, Yan P, and Qin S. 2018. Responses of soil microbial communities to a short-term application of seaweed fertilizer revealed by deep amplicon sequencing. Applied Soil Ecology 125:288-296. https://doi.org/10.1016/j.apsoil.2018.02.013

Wang Q, Garrity GM, Tiedje JM, and Cole JR. 2007. Naïve Bayesian Classifier for Rapid Assignment of rRNA Sequences into the New Bacterial Taxonomy. Applied and Environmental Microbiology 73:52615267. 10.1128/aem.00062-07

Wang X, Shen J, and Zhang W. 2014. Emergy evaluation of agricultural sustainability of Northwest China before and after the grain-for-green policy. Energy Policy 67:508-516. http://dx.doi.org/10.1016/j.enpol.2013.12.060 Weon H-Y, Kim B-Y, Kim M-K, Yoo S-H, Kwon S-W, Go S-J, and Stackebrandt E. 2007. Lysobacter niabensis sp. nov. and Lysobacter niastensis sp. nov., isolated from greenhouse soils in Korea. International Journal of Systematic and Evolutionary Microbiology 57:548-551. doi:10.1099/ijs.0.644730

Wick B, Kühne RF, and Vlek PLG. 1998. Soil microbiological parameters as indicators of soil quality under improved fallow management systems in south-western Nigeria. Plant and Soil 202:97-107. 10.1023/A:1004305615397

Yao H, Bowman D, and Shi W. 2011. Seasonal variations of soil microbial biomass and activity in warmand cool-season turfgrass systems. Soil Biology and Biochemistry 43:1536-1543.

https://doi.org/10.1016/j.soilbio.2011.03.031

Zak DR, Holmes WE, White DC, Peacock AD, and Tilman D. 2003. PLANT DIVERSITY, SOIL MICROBIAL COMMUNITIES, AND ECOSYSTEM FUNCTION: ARE THERE ANY LINKS? Ecology 84:2042-2050. doi:10.1890/02-0433

Zhang Q, Zhou W, Liang G, Wang X, Sun J, He P, and Li L. 2015. Effects of Different Organic Manures on the Biochemical and Microbial Characteristics of Albic Paddy Soil in a Short-Term Experiment. PLOS ONE 10:e0124096. 10.1371/journal.pone.0124096 
Figure $\mathbf{1}$ (on next page)

The principal component analysis for soil physicochemical properties in different months. 

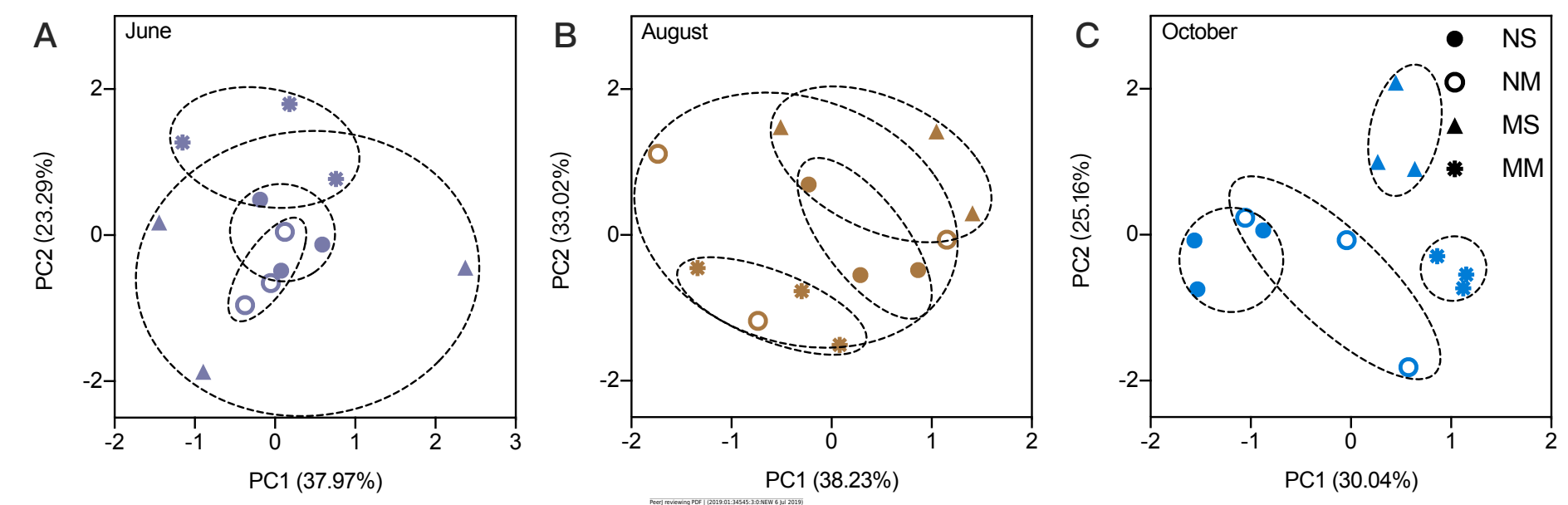


\section{Figure 2 (on next page)}

The comparison of differences among fallow management on soil properties, based on two-way ANOVA.

The plots, which were marked upper- and lowercase, represented the interaction factor's impact was significant. And the uppercase means the fertilization impacts and the lowercase means the vegetation impact (the simple effect test was used to analyze the significance of the difference). The plots which were only impacted by a principal factor, the name of the factor was marked in the upper right corner of each plot. *,** and ${ }^{* * *}$ are used to show statistical significance at the $0.05,0.01$, and 0.001 level, respectively. SOC means soil organic carbon; TN means total nitrogen; $\mathrm{C} / \mathrm{N}$ means the ratio of organic carbon to total nitrogen; MBC means microbial biomass carbon; MBN means microbial biomass nitrogen; MBC/MBN means the ratio of microbial biomass carbon to microbial biomass nitrogen; $\mathrm{NH}_{4}{ }^{+}-\mathrm{N}$ represents ammonia nitrogen. 
Figure 3 (on next page)

Nonmetric multidimensional scaling ordination (NMDS) of soil bacteria.

Different colors represent seasons and the shapes represent different fallow managements. 

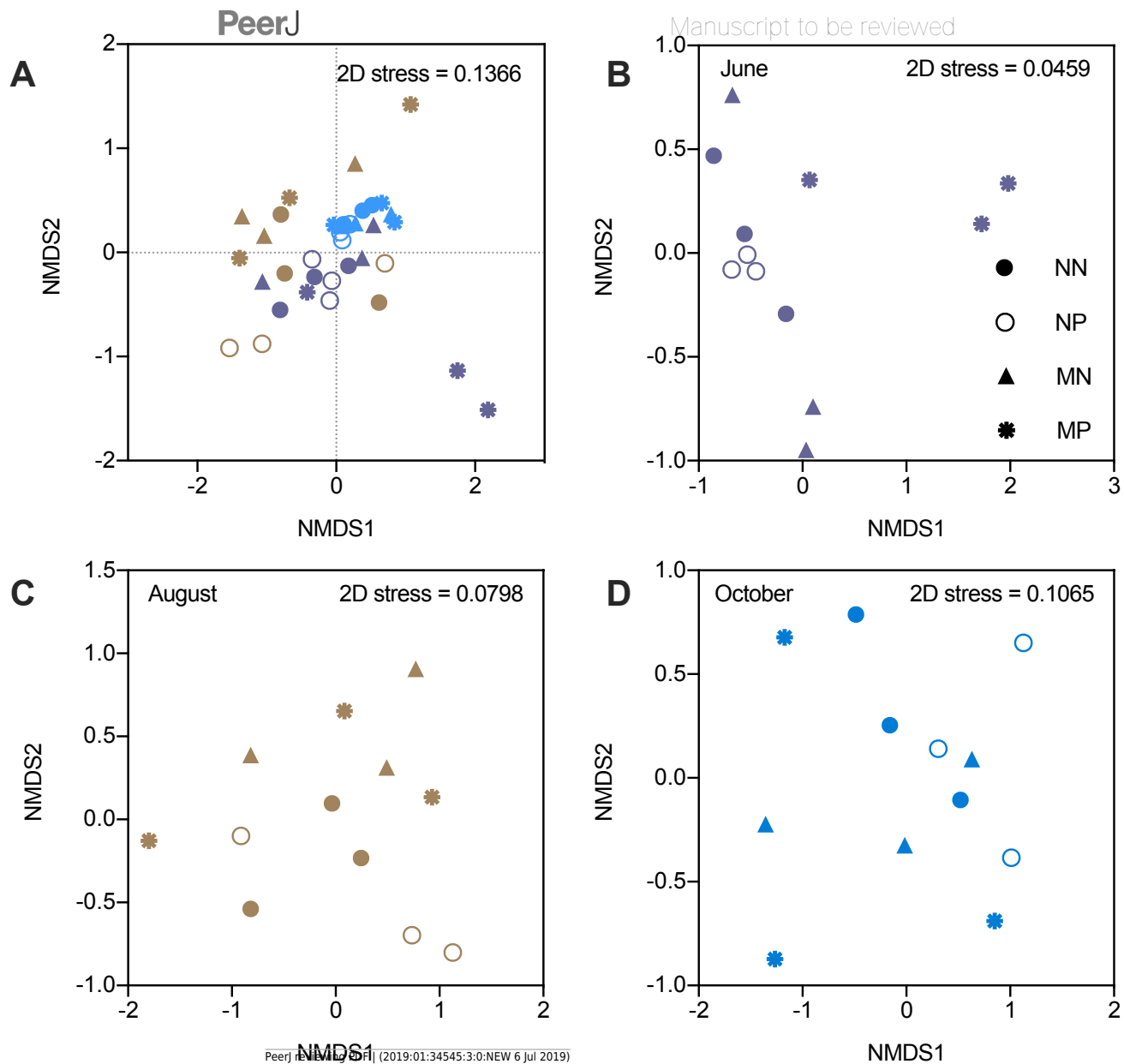
Figure 4 (on next page)

The relative abundance of dominant bacteria in different groups and seasons, and a mosaic site in relation to treatments in different months, based on ANOVA.

The relative abundance of dominant genera in different groups and seasons (a) and a mosaic site in relation to treatments in different months and time factor (b), and significant responses of dominated genera based on two-way ANOVA ( $P<0.05$, blue color). Relative abundance stacked barplot (c) of microbial taxa (Phylum level). 


\section{A \\ PeerJ}

Thaumarchaeota / Nitrososphaera

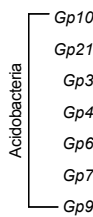

Actinobacteria / Gaiella

Bacteroidetes / Ohtaekwangia

Chloroflexi / Sphaerobacter

Gemmatimonadetes / Gemmatimonas

Nitrospirae / Nitrospira

Planctomycetes $\begin{array}{r}\text { Blastopirellula } \\ \text { Pirellula }\end{array}$

Geminicoccus
Ramlibacter
Steroidobacter
Luteimonas
L
Lysobacter

NS NM MS MM NS NM MS MM NS NM MS MM

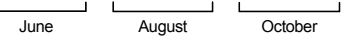

\section{Manuscripß to be reviewed}

August

October

Nitrososphaera

Gp10

Gp21

Gp3

Gp4

Gp6

Gp7

Gp9

ญั

Gaiella

Ohtaekwangia

Sphaerobacter

Gemmatimonas

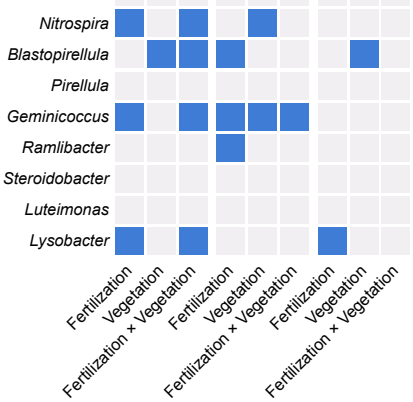

Fallow treatments
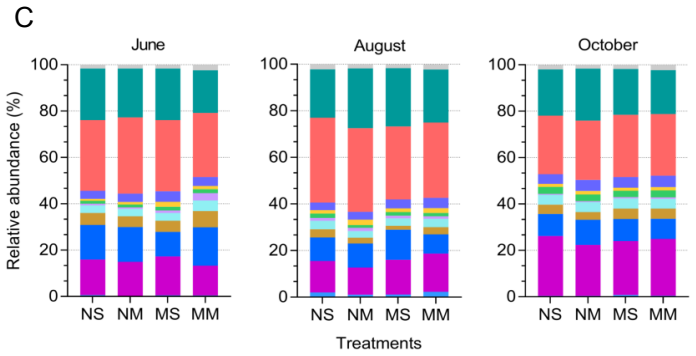

- Others

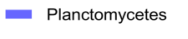

- Firmicutes

- unclassified Bacteria

- Nitrospirae

- Chloroflexi

- Proteobacteria

- Actinobacteria

- Bacteroidetes

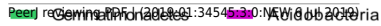

Thaumarchaeota 


\section{Table 1 (on next page)}

The correlation between soil properties and selected genera. 


\begin{tabular}{llll}
\hline Soil variables & Gp6 & Blastopirellula & Lysobacter \\
\hline $\mathrm{pH}$ & $-0.632 * * *$ & -0.304 & $-0.483 * *$ \\
$\mathrm{SOC}$ & 0.016 & -0.033 & $-0.359 *$ \\
$\mathrm{TN}$ & -0.090 & -0.280 & -0.281 \\
$\mathrm{C} / \mathrm{N}$ & 0.027 & 0.081 & -0.148 \\
$\mathrm{MBC}$ & -0.021 & 0.041 & 0.100 \\
$\mathrm{MBN}$ & 0.237 & $0.485 * *$ & 0.293 \\
$\mathrm{MBC}^{\mathrm{MBN}}$ & -0.181 & $-0.357 *$ & -0.152 \\
$\mathrm{NH}_{4}^{+}-\mathrm{N}$ & -0.265 & -0.314 & -0.257 \\
\hline
\end{tabular}

$\dagger *, * *$ and *** are used to show statistical significance at the $0.05,0.01$, and 0.001 level, respectively. SOC means soil organic carbon; $\mathrm{TN}$ means total nitrogen; $\mathrm{C} / \mathrm{N}$ means the ratio of organic carbon to total nitrogen; $\mathrm{MBC}$ means microbial biomass carbon; $\mathrm{MBN}$ means microbial biomass nitrogen; $\mathrm{MBC} / \mathrm{MBN}$ means the ratio of microbial biomass carbon to microbial biomass nitrogen; $\mathrm{NH}_{4}{ }^{+}-\mathrm{N}$ represents ammonia nitrogen. 